\title{
Factors influencing managers' attitudes towards performance appraisal
}

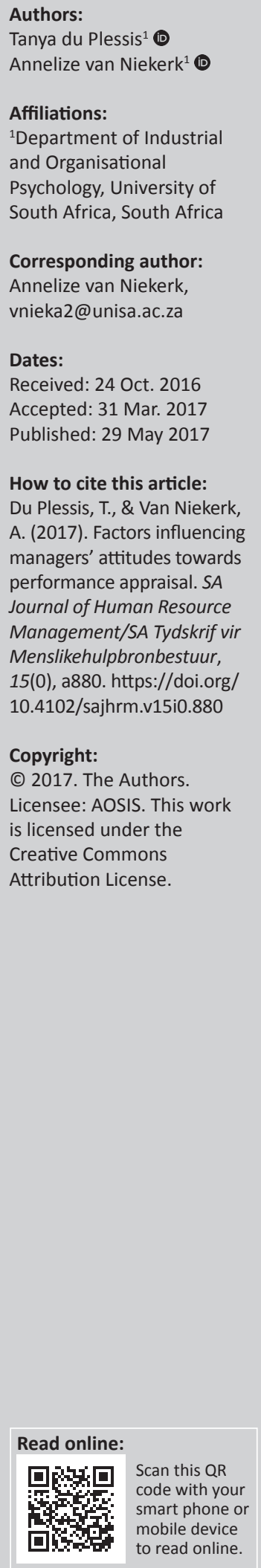

Orientation: Managers often have negative attitudes towards performance appraisal because of its problematic nature, which is influenced by political and social contextual factors. These negative attitudes lead to reduced employee support, inaccurate performance appraisal ratings and, consequently, negative employee perceptions of the performance appraisal process. This state of affairs necessitates a deeper understanding of the factors influencing managers' attitudes towards performance appraisal.

Research purpose: The purpose of this research was to gain a deeper understanding of the factors that influence managers' attitudes towards performance appraisal.

Motivation for the study: Previous research has confirmed the importance of performance appraisals in organisations. However, managers' dislike of and aversion to performance appraisal impact negatively on the effectiveness of performance appraisal systems and ultimately the development and performance of employees.

Research design, approach and method: An interpretivist qualitative study was adopted, utilising naïve sketches and in-depth interviews to collect data from eight managers, purposively selected. The data were analysed by using Tesch's descriptive data analysis technique.

Main findings: This study revealed that performance appraisal is fundamentally an uncomfortable and emotional process for managers, which results in their adopting defensive attitudes. Because of many uncertainties, managers do not always display the ability or readiness to conduct performance appraisals. The organisational context might place the individual manager in a position to distort employee ratings, which in turn negatively influences that manager's attitude.

Practical and managerial implications: This study provides insight into the present-day experience of managers in respect of performance appraisal and highlights the factors that influence their attitudes.

Contribution: The insight gained from this research into the factors impacting on the attitude of managers towards performance appraisals can assist organisations to better support and empower such managers to be more effective in their approach when conducting performance appraisals.

\section{Introduction}

Performance appraisal has, for many years, been regarded as a critical process aimed at improving employee performance and, ultimately, organisational effectiveness (Cascio \& Aguinis, 2011; Swanepoel, Botha \& Mangonyane, 2014). Frustration with performance appraisal is more evident than ever, and voices opposing the use thereof are increasing and growing louder (Adler et al., 2016; Kondrasuk, 2012; MacDonald \& Sulsky, 2009).

Performance appraisal is known to be a critical but complex component within performance management, and it holds many advantages (Cascio \& Aguinis, 2011; Grote, 2011). Performance appraisal has been utilised by organisations as a tool through which strengths and developmental areas of employees can be described and to facilitate the relationship between the employee and the manager (Pichler, 2012). Performance appraisal is also used as a mechanism through which decisions relating to salary increases and succession planning are informed (Grote, 2011). However, performance appraisal is also associated with negativity and dissatisfaction among managers

Note: This article is partially based on the author's thesis for the degree of Masters in Commerce in Industrial and Organisational Psychology at the University of South Africa, South Africa, with supervisor Mrs Annelize van Niekerk, received February 2015, available here: $\mathrm{http}$ ://uir.unisa.ac.za/bitstream/handle/10500/19158/dissertation_du\%20plessis_esct.pdf?isAllowed=y\&sequence=1 
(Cascio \& Aguinis, 2011; Gordon \& Stewart, 2009). Different views exist on this issue, but it seems that the challenges with performance appraisal emanate from the accuracy of employee performance ratings (Botha \& Bussin, 2010; Shore \& Strauss, 2008). Reasons for inaccurate performance ratings include among others:

- Distorted performance ratings as a result of managers' personal motives (Longenecker \& Gioia, 2003).

- Managers' lack of commitment to performance appraisals (Tziner, Murphy \& Cleveland, 2002).

- Managers fear performance appraisal as they experience it to be a challenge (Torrington, Hall, Taylor \& Atkinson, 2009).

- Managers dread the possibility of damaging relationships with employees (Pulakos, 2011).

- Political motives embedded in longstanding relationships with employees (Shore \& Strauss, 2008; Swanepoel et al., 2014).

- The organisational culture, norms, goals and manager attitude (Botha \& Bussin, 2010).

- The presence of emotional uneasiness, conflict and failure to provide constructive feedback (Marreli, 2011).

- The fact that some managers perceive inaccuracies in performance ratings not as errors, but as enablers, which motivate and retain staff (Cascio \& Aguinis, 2011).

It is therefore proposed that, by gaining a better understanding of the factors that influence the managers' experiences and attitudes - both positively and negatively - towards performance appraisal, organisations and managers may be enabled to conduct more effective and accurate performance appraisals and thereby enhance employee performance and development.

\section{Research purpose}

Several studies previously explored factors that influence the attitude of managers towards performance appraisal (Botha \& Bussin, 2010; Cascio \& Aguinis, 2011). However, the work environment and context continuously change - as do the factors influencing managers' attitudes - resulting in managers approaching performance appraisal with a certain level of trepidation. Most recent studies have focused on employees' perceptions of the fairness of performance appraisal, consequently leaving a knowledge gap as to the factors impacting on managers' attitudes towards performance appraisal (Dusterhoff, Cunningham \& MacGregor, 2014; Jacobs, Belschak \& Den Hartog, 2014).

The prevailing attitudes of managers have a severe impact on the entire performance appraisal, including the accuracy of performance appraisal ratings (Botha \& Bussin, 2010; Marmet, 2015). Managers viewing performance appraisal as positive tend to give more accurate ratings (Jawahar, 2001). Regrettably, there seems to be no consensus on an effective working solution to address manager attitudes and their impact of accurate performance appraisal ratings; consequently, displeasure with performance appraisal persists (Gordon \& Stewart, 2009; Swanepoel et al., 2014). In order to influence managers' attitudes towards performance appraisal more positively, this study was aimed at gaining a deeper understanding of the factors that influence managers' existing attitudes towards performance appraisal. The study proposes that by gaining a better understanding of the present-day factors that influence manager attitudes towards performance appraisal, more effective interventions can be developed that will result in not only a more positive experience on the part of managers, but that will also enhance employee development and performance.

\section{Literature review Performance appraisal}

Performance management is an ongoing process where the performance of individuals and teams is identified, measured and developed through the process of performance appraisal (Aguinis, 2009; Cascio \& Aguinis, 2011; Shore \& Strauss, 2008). Performance appraisal can be defined as the collection of employee performance information based on observation and the evaluation of the employee's performance through an act of judgement (Cascio \& Aguinis, 2011). Once an employee's current performance is measured, performance developmental areas are identified, strengths are reinforced and overall feedback is given to the employee (Aguinis, 2009; Swanepoel et al., 2014). As a manager's attitude can negatively or positively influence a performance appraisal, many researchers have, over the years, found this to be an interesting topic to study (Curtis, Harvey \& Ravden, 2005; Jawahar, 2001; Longenecker, Sims \& Gioia, 1987; Shore \& Strauss, 2008; Thomas \& Bretz, 1994). However, because of the attitude of the manager who conducts them, performance appraisals seem to remain a challenge to organisations.

\section{Attitude}

What, then, is an attitude? Thurstone (1931) proposed that an attitude was something that relates to an individual's preferences towards an object. According to Allport (1935), an attitude points to a psychological type of readiness that is formed by applying a judgement towards an object through experience. Taking it one step further, Eagly and Chaiken (1993) define an attitude as a psychological tendency (an internal state) that is expressed by evaluating a particular entity with some degree of favour or disfavour. Attitudes therefore serve as functions to evaluate objects of thought, to process information, to adjust behaviour accordingly, to use as a protection mechanism and with which to display individual values (Fazio \& Petty, 2008; Katz, 1960; Pratkanis, 2014).

Attitudes can form in various ways (Luthans, 2008; Miserandino, 2007; Vogel \& Wänke, 2016; Zhang, Xie, Wee, Thumboo \& Li, 2008). Firstly, through situations where a person's behaviour is not consistent with his or her attitudes towards the specific object. A negative attitude towards an object then forms to balance such inconsistency. Secondly, attitudes can form through learning, for example with 
reinforcements such as positive encouragement. Another method requires the pairing of two stimuli until a situation is reached where the first stimulus transforms into a signal for the second stimulus. An attitude can be created where a neutral target stimulus (conditioned stimulus) is repeatedly paired with another stimulus (unconditioned stimulus) with either a positive or negative valence which can then, in turn, change the person's attitude in line with the direction of the unconditioned stimulus. Lastly, attitudes can form through the expectancy-value framework, a theory that assumes that the attitude towards the object is based on the sum of the values of all of the attributes that the attitude object is thought to have, and which is based on the mental formation of attitudes. This framework is a useful and popular model to explain how a collection of beliefs about objects forms attitudes. The expectancy-value framework attitude formation theory was adopted for this study (Zhang et al., 2008).

\section{Attitude and performance appraisal}

In a study conducted by Longenecker et al. (1987), political motivation, the degree of trust in the relationship between employees and managers, and the need to avoid confrontation with difficult employees are proposed as elements, which impact on how a manager approaches and performs an appraisal and which subsequently influence the performance ratings that such a manager allocates to employees.

A few years later, Bretz and Milkovich (1992) conducted a study which aimed to investigate how performance appraisal was practised in the workplace. Their study reported a lack of manager ownership with managers feeling that they were excluded during the decision-making process and implementation of performance appraisal systems.

Similar studies exploring the factors impacting on managers' attitudes towards performance appraisals have examined the following:

- Managers' dislike towards the idea of influencing an employee's career (Thomas \& Bretz, 1994).

- The manager's own level of motivation (Harris, 1994).

- The manager's view of the purpose of performance appraisal (Tziner, Lathan, Price \& Haccoun, 1996).

- The manager's attitude towards the organisation (Tziner \& Murphy, 1999).

- The manager's own personality preference as well as confidence in the performance appraisal system (Tziner et al., 2002).

- The employees' expectations (Curtis et al., 2005; Yun, Donahue, Dudley \& McFarland, 2005).

- The manager's perception of the organisational context as well as affection towards the employee (Shore \& Strauss, 2008).

- Performance appraisal skills and managers' motives (MacDonald \& Sulsky, 2009).

- Conflicting roles, such as playing both a judge and a coach during performance appraisal (Aguinis, 2009).

- Terminology in performance appraisal that is confusing (Van De Mieroop \& Vrolix, 2014).
Performance appraisal is a critical process and is viewed as one of the processes that have the greatest effect on the employee's career and development (Aguinis, 2009; BayoMoriones, Galdon-Sanchez \& Martinez-de-Morentin, 2016; Grote, 2011). Therefore, in order to stay current and influence managers' attitudes positively towards performance appraisal, this study sought to gain a deeper understanding of the contemporary factors that influence managers' attitudes towards performance appraisal.

\section{Research design Research approach}

This study adopted a qualitative research approach as it aimed at producing rich, nuanced and detailed data (Mason, 2012). Participants could share their personal performance appraisal experiences and, consequently, a complex and detailed understanding of the factors influencing these experiences was gained (Creswell, 2014; De Vos, Strydom, Schulze \& Patel, 2012; Henning, Van Rensburg \& Smit, 2012).

\section{Research strategy}

In line with the interpretive paradigm, in-depth interviews were used to generate rich data as to participants' experiences, perceptions and feelings (Mason, 2012; Pietkiewicz \& Smith, 2014). The in-depth interviews moved from being general in nature to being specific and were conducted in four phases, namely opening, questioning, probing and closing (Kolb, 2008). Two non-leading questions laid the foundation for the in-depth interview and were followed by follow-up questions and probes intended to build better, unrestricted understanding (Pietkiewicz \& Smith, 2014). The two non-leading questions also provided direction for the naïve sketches. The managers responsible for performance appraisals in an organisation in the financial services sector were selected as the unit of analysis in this study.

\section{Research method Research setting}

This research was conducted in the private sector at a medium-sized financial services organisation. The indepth interviews were conducted with eight managers responsible for conducting performance appraisals on their subordinates and at a venue that was comfortable and private so as to prevent disturbances.

\section{Entrée and establishing researcher roles}

Consent was obtained from the organisation's Executive Director of Human Capital to conduct the study. Background information and the aims of the study were discussed with potential candidates. Once the candidates agreed to participate, they completed an informed consent form outlining the scope of the study and how ethical and confidentiality issues would be attended to. 


\section{Sampling}

A purposive sample of eight participants was selected based on availability (De Vos et al., 2012; Durrheim \& Painter, 2006) and aimed to represent managers from different ethnic groups (African, Indian and white), ages (30-70 years), genders (five female and three male) and the number of years' experience (from 1 to 35 years) in performance appraisal.

\section{Data collection methods}

In-depth interviews were conducted with the eight managers in order to gain a deeper understanding of their experiences, interpretations and perceptions of performance appraisals (Mason, 2012). Two questions were asked of the participants: 'Tell me about your overall experience with performance appraisal' and 'What are the positive and negative factors that influenced your attitude towards performance appraisal?'

The secondary method of data collection was naïve sketches, which refer to a description of certain phenomena in the form of a short story (Giorgi, 1985). The naïve sketches were obtained through requesting each manager to draw a picture or write a narrative about their experiences with performance appraisal, highlighting the positive and negative factors that they believe have influenced their attitudes towards performance appraisal.

\section{Recording of data}

Eight naïve sketches were collected. The in-depth interviews were recorded using an audio recorder and were transcribed verbatim. Field notes were taken during the interviews to capture the context as well as the researcher's observations, perceptions and experiences during these interviews (Greef, 2012). The data were stored securely and protected with passwords with only the researcher having access to them.

\section{Data analysis}

The verbatim transcriptions of the recorded in-depth interviews and the naive sketches were analysed in accordance with Tesch's descriptive analysis technique (Creswell, 2014). All transcriptions and narratives were read once to get a holistic sense of their content, after which ideas that came to mind were documented. Sub-themes were identified and grouped into major sub-themes, unique subthemes and leftovers. This list of sub-themes was used to code the data. The most descriptive wording for each subtheme was taken, converted into main themes and the data organised so that similar sub-themes were grouped. Interrelationships between the sub-themes were found and codes were generated. All of the data that were related to one main theme were highlighted in a certain colour and assembled together. Afterwards, the data were recorded to ensure that no sub-themes had been ignored.

\section{Strategies ensuring quality data and ethics}

As required by an interpretative study, it was ensured that the researcher was skilled in using the self as an instrument to collect and analyse the data (Terre Blanche et al., 2006). The researcher kept field notes of her own personal experiences, biases, prejudices and orientations, which might have influenced the recording and interpretation of the information and regularly referred to and reflected on these notes to reduce possible bias (Creswell, 2014).

The researcher assessed the quality of the data and the rigour of the process to ensure that the generated findings would be credible, transferable, dependable and conformable (Schurink, Fouche \& De Vos, 2012). Credibility was ensured through member checking (Creswell, 2014; Rossmann \& Rallis, 2011). Triangulation was applied in utilising two data collection methods, namely in-depth interviews and naïve sketches, in order to enhance the credibility and trustworthiness of the study (Shah \& Corley, 2006).

The transferability of the study was ensured through providing detailed descriptions of both the research methodology followed as well as the findings obtained (Babbie, 2010; Shah \& Corley, 2006). Transferability was further enhanced by ensuring that all of the in-depth interviews were conducted and naïve sketches were collected within the same period so as to eliminate possible influences (Babbie, 2010). Dependability was ensured through being consistent in employing purposive sampling and applying the data collection and data analysis techniques (Shah \& Corley, 2006). Confirmability was obtained through rigorous data management of the verbatim transcriptions, collected naïve sketches, field notes taken of observations during the in-depth interviews and accurate record-keeping (Rossman \& Rallis, 2011; Shah \& Corley, 2006).

\section{Reporting}

The findings of the study were reported by utilising a qualitative, narrative reporting style (Visagie \& Maritz, 2009). Themes and sub-themes are discussed and supported with evidence from the most descriptive verbatim quotations and findings are integrated with literature to explain the data and to indicate the relevance of the findings in relation to the current body of literature (Henning et al., 2012).

\section{Findings}

This section portrays the overall findings obtained from the eight in-depth interviews and naïve sketches and presents the main themes and sub-themes as depicted in Table 1.

\section{Theme 1: The employee}

The theme of employee-related factors yielded two subthemes, namely employee behaviour and attitudes; and the role of employees in performance appraisal.

\section{Employee behaviour and attitudes}

The participants all agree that performance appraisals are an emotionally loaded experience. Participant 3 particularly points to the unpredictable and varying nature of emotions a 
TABLE 1: Grouping findings into main themes and sub-themes.

\begin{tabular}{|c|c|c|}
\hline Theme & Sub-themes & Properties \\
\hline \multirow[t]{2}{*}{$\begin{array}{l}\text { Theme 1: The } \\
\text { employee }\end{array}$} & $\begin{array}{l}\text { Employee behaviour and } \\
\text { attitudes }\end{array}$ & $\begin{array}{l}\text { - Emotional employees } \\
\text { - Defensive employees } \\
\text { - Performance of employees }\end{array}$ \\
\hline & Role of the employee & $\begin{array}{l}\text { - Employee ownership } \\
\text { - Inflated performance ratings } \\
\text { - Employee-manager relationship }\end{array}$ \\
\hline $\begin{array}{l}\text { Theme 2: The } \\
\text { manager }\end{array}$ & $\begin{array}{l}\text { Experience as a ratee and } \\
\text { rater }\end{array}$ & $\begin{array}{l}\text { - Limited experience and lack of } \\
\text { exposure and guidance }\end{array}$ \\
\hline $\begin{array}{l}\text { Theme 3: Senior } \\
\text { management }\end{array}$ & $\begin{array}{l}\text { Senior managements role } \\
\text { and directive }\end{array}$ & $\begin{array}{l}\text { - Strategic } \\
\text { - Unethical frameworks }\end{array}$ \\
\hline \multirow{4}{*}{$\begin{array}{l}\text { Theme 4: The } \\
\text { performance } \\
\text { appraisal }\end{array}$} & $\begin{array}{l}\text { Uncertain purpose of } \\
\text { performance appraisal }\end{array}$ & - Varying views \\
\hline & $\begin{array}{l}\text { What is measured and } \\
\text { how? }\end{array}$ & $\begin{array}{l}\text { - What employee information? } \\
\text { - Objective vs. subjective }\end{array}$ \\
\hline & $\begin{array}{l}\text { Frequency of performance } \\
\text { appraisal }\end{array}$ & - Quarterly vs. annual \\
\hline & Type of feedback & $\begin{array}{l}\text { - Positive vs. negative feedback } \\
\text { - Personality preferences }\end{array}$ \\
\hline
\end{tabular}

manager is sometimes confronted with and 'as a manager, it is not a moment that you can enjoy ... and it becomes very difficult' (Participant 3, male, African, 1 year of experience with performance appraisal).

The defensive attitude of employees certainly seems to be a factor impacting on the attitudes of managers towards performance appraisal. Participants 4 and 5 are of the opinion that employees acquire defensive attitudes prior to or during the performance appraisal feedback meeting and that managers dislike handling such defensive employees. Participant 6 agrees but had also experienced an employee who adopted such a defensive attitude as enjoying it: 'The particular person who was being appraised thoroughly enjoyed it. He enjoyed that sort of thing, but it wasn't a pleasant experience for the manager' (Participant 6, male, white, 35 years of experience with performance appraisal).

Most participants agree that conducting performance appraisals with employees who meet the required performance expectations is much less challenging than those with employees not meeting expectations. However, conducting a performance appraisal with an employee who did not meet the set performance expectations requires more effort and even an attitude adjustment on behalf of the manager. As Participant 4 explains: ' ... that difficult guy who is not a top performer is walking in there, you have to on a personal level set your attitude ...' (Participant 4, female, white, 5 years of experience with performance appraisal).

\section{The role of employees}

The role employees fulfil during a performance appraisal and the manner in which they execute it seem to influence the attitude the manager concerned adopts during a performance appraisal. The first factor points to the ownership employees take with regard to their performance and the appraisal thereof. Both Participants 1 and 3 highlighted the importance of employees taking ownership of the performance appraisal process. Employees should be well informed as regards the performance appraisal process and be made aware that they are valued. When the employee feels valued and experiences a sense of belonging, managers experience the performance appraisal process as more comfortable and less threatening.

The second factor relates to employees inflating their performance ratings. When managers have to rate employees lower on their actual performance in comparison with a higher employee self-rating, it becomes an unpleasant experience. Participants 4, 5 and 7 state that this is even more so the case when employees are unable to substantiate their own inflated self-ratings with sufficient evidence. Participant 6 agrees, personally experiencing such employees as being dishonest. Participant 4 further highlights how '... staff lives with the idyllic idea that they are much better performers than what they actually are ... even constant feedback and critic are disregarded and set aside' (Participant 4, female, white, 11 years of experience with performance appraisal), and this disregard for feedback from the managers further impacts negatively on the attitude of the manager.

The third factor relates to the strength of the employeemanager relationship and its foundational characteristics such as open communication and trust. Participant 2 highlights the importance of continuous, open communication as 'communication is very important and with the workload we're sitting with it is not always possible to communicate with your staff all the time and that is an influence ...'; however, regular communication seems to be important so as 'to ensure that there is a good understanding of what is expected' (Participant 2, female, white, 5 years of experience with performance appraisal). Participant 6 points to the importance of a relationship of trust between the employee and manager and to how this simplifies the performance appraisal. In order to establish this trust relationship, Participant 3 feels it is important to strike a balance between being the manager and getting the task done against building a relationship with the employee.

\section{Theme 2: The manager}

Another prominent theme emerging from the data relates specifically to the manager. The sub-theme which emerged is concerned with the manager's previous experience gained in both the role of ratee (the employee whose performance is appraised) and rater (the manager who conducts a performance appraisal with an employee).

\section{Experience as ratee and rater}

As ratees, managers highlight how they mostly received positive performance feedback from their managers and therefore have gained limited experience and exposure as to how a performance appraisal containing negative feedback should be handled. Like most other participants, Participant 2 voices this as follows: 'I've never been in a situation where I could see how the other person handles a negative appraisal' (Participant 2, female, white, 5 years of experience with performance appraisal).

This lack of exposure seems to impact negatively on a manager's own readiness and ability to deal with negative 
performance appraisals in his or her role as rater. According to Participants 2 and 5, having had limited previous experience, exposure or guidelines on how to conduct a performance appraisal as a rater meant that a performance appraisal that contained negative performance feedback was an unpleasant experience for them. Participant 2, however, points to how 'you get used to it and get to learn it. Obviously as you get to learn to deal with people, it becomes easier' (Participant 2, Female, white, 5 years of experience with performance appraisal). Participant 1 , a more experienced manager, seems to sympathise with new managers who have to deal with this uncertainty and points to the importance and value of guidance and mentoring.

\section{Theme 3: Senior management}

The influence of senior management emerged as a third theme from the data. This theme incorporates the sub-themes of the role of senior management and their subsequent directives as contained through frameworks in accordance with which performance appraisals are managed.

\section{Senior management's role and directive}

Participants are of the opinion that senior managers play a strategic role in ensuring the effectiveness of performance appraisal and that it should be implemented following a topdown approach. Participant 1 believes that ' when performance appraisal is driven and led by senior management, it works for the company' (Participant 1, Male, Indian, 15 years of experience with performance appraisal).

In this role, senior management also directs managers through frameworks on how they should conduct the performance appraisal. A substantial number of the managers were of the opinion that these frameworks have a significant influence on the attitudes of managers towards performance appraisals.

These frameworks might require the manager to inflate or deflate the employees' performance ratings. Participant 2 shares an experience where 'you are told that you have to make sure that your appraisal falls within the scale, which then makes it difficult for me to manage' (Participant 2, female, white, 5 years of experience with performance appraisal). Participant 4 had a similar experience and elaborates:

it is difficult because that influence your attitude towards the process. Is it really fair? And you are the one who has to sit with that employee and there is nothing worst. And I mean you don't want to lie to that staff member who sits in front of you, because that is not your purpose that's not what you are there for. That makes it a yucky process and a difficult process and it starts making it in an emotional process. (Participant 4 , female, white, 11 years of experience with performance appraisal)

Subsequently, managers seem to struggle with the execution of frameworks they believe to be unethical, and this affects them emotionally, resulting in negative attitudes towards performance appraisals.

\section{Theme 4: The performance appraisal}

Theme four is the most prominent theme that emerged from the data and relates more specifically to the performance appraisal itself. Four sub-themes emerged and these incorporate the clear purpose of the performance appraisal; problems relating to what is measured and how it is measured; the frequency of the performance appraisal; and the type of performance feedback.

\section{Uncertain purpose of performance appraisal}

Participants highlight the importance of a performance appraisal having a clear purpose. Even though they are all employed in the same organisation, they all seem to have different views on exactly what the purpose of performance appraisal in their organisation is. Participant 1 views a performance appraisal as 'a tool to get to a result in a very objective way' and emphasises the importance of reinforcing the objectives 'as often as performance appraisals are conducted' (Participant 1, male, Indian, 15 years of experience with performance appraisal).

According to Participant 6, performance appraisal is merely an administrative tool used by organisations to calculate salary increases. Participant 8 , on the other hand, views the purpose of performance appraisal differently and believes it has a positive element to it and can be used:

as a management tool ... to see where your staff is currently, what factors can help them to do their job better, faster more accurate and to get them there. (Participant 8 , female, white, 4 years of experience with performance appraisal)

\section{What is measured and how?}

The second sub-theme that emerged from the data pertains to what a performance appraisal should measure and how. Most participants revealed their uncertainty as to what employee information they should use during a performance appraisal and how they should utilise this information in allocating ratings. According to Participant 1 there are:

two parts to the appraisal. One is factual ... how you deliver, are you punctual on delivery times. Then there is the second part which is airy fairy ... and you know when something is not clear and to the point it leads to a lot of debate unnecessary. (Participant 1, male, Indian, 15 years of experience with performance appraisal)

\section{Participant 4 agrees, stating:}

I believe in factual and statistical information and as long as you have that, it cannot be left questioned, open for interpretation and it cannot be left open for a personal attack. (Participant 4, female, white, 11 years of experience with performance appraisal)

Participants indicate a clear preference to use objective or factual information and state clearly how they find it challenging to rate employees on subjective data because such ratings are open to interpretation and may create conflict situations between the manager and employee. 


\section{Frequency of performance appraisals}

The frequency with which performance appraisals are conducted is another factor that impacts on the attitude of managers. Performance appraisals conducted only annually seem to be experienced by Participant 8 as excessively time consuming because of the large amount of information that has to be dealt with. All participants agree with Participant 8 and expressed a strong preference for rather conducting performance appraisals more frequently as they believe that this would enhance objectivity and fairness, assist employees to achieve their goals more successfully and also make the process less emotional.

\section{Type of feedback}

Participants shared their preference for performance appraisals in which they give positive feedback and where their final rating is equal or higher than that of the employees' self-rating, as this results in performance appraisal being a rewarding experience. On the other hand, having to give employees feedback that is regarded as negative because of the manager's score being lower than the employees' selfrating is experienced by the participants as unpleasant and quite emotional. Participants 6 and 7 clearly indicated their preference for shying away from giving negative feedback. Participant 6 prefers to rather 'grade people up' as it is less unpleasant (Participant 6, male, white, 35 years of experience with performance appraisal). Contrary to the above participants, Participant 8 feels that negative feedback is expected and mostly required as 'you don't have time to give positive feedback. You always have time to give negative feedback because you have to' (Participant 8, female, white, 4 years of experience with performance appraisal).

Participant 2 points to the influence of the manager's personality and how it impacts on his or her attitude towards performance appraisals. According to Participant 2, handling performance appraisals effectively is a skill and ability that needs to be developed 'where you need to learn to cut off and handle it professionally' (Participant 2, female, white, 5 years of experience with performance appraisal). Participant 2 further proposes:

negative feedback must be given through as positive criticism ... my personal challenge with this is that we have varied types of personalities and different personalities accept positive criticism in different ways. (Participant 2, Female, white, 5 years of experience with performance appraisal)

\section{Discussion}

\section{Outline of the findings}

The aim of this research was to gain a deeper understanding of the factors that influence managers' attitudes towards performance appraisal. Performance appraisal is generally experienced as a negative process (Cascio \& Aguinis, 2011; Gordon \& Stewart, 2009). As managers are fundamental to the process of performance appraisal it is important to explore and better understand the factors that impact negatively on their attitudes towards performance appraisal.
Being able to positively influence managers' experience of and subsequent attitudes towards performance appraisal should result in more accurate performance ratings as well as in improving the support provided to employees by managers (Botha \& Bussin, 2010).

The findings of this study re-emphasised the influence emotional and defensive employees have on the attitude of managers towards performance appraisals (Aguinis, 2009; Thomas \& Bretz, 1994). Employees who become emotional when they receive negative performance feedback and subsequently behave in a hostile and/or defensive manner impact negatively on the attitudes of managers towards performance appraisals.

The findings further point to the importance of managers and employees taking ownership of the performance appraisal process. Lack of ownership is a result of managers and employees feeling that they have not been consulted during the design phase of the performance appraisal process and thus do not own it. Based on the above findings it can be concluded that managers should be well trained on both the process to be followed and that they should receive coaching and guidance on how to conduct feedback (positive and negative) as this will empower them and improve the experience and quality of performance appraisal (Hii \& Ahmad, 2015).

From the findings it is evident that managers have favourable attitudes towards performance appraisal when the performance of the ratee complies with the expected performance and when the employee's self-appraisal ratings are similar to the ratings assigned by the managers. Botha and Bussin (2010) agree as ratings are based on an employee's or manager's subjective view of the performance and, consequently, such ratings might be inflated, thus resulting in the appraisal being experienced as uncomfortable. The findings furthermore indicate that the relationship between the manager and the employee influences the manager's attitude. The importance of a healthy relationship built on continuous communication between employee and manager is acknowledged (Pulakos \& O'Leary, 2011). However, during a performance appraisal the value of such a relationship is often not visible, especially when the relationship has been long standing. Studies indicate that managers often choose to inflate or deflate performance ratings as they are fearful of harming the employee-manager relationship (Aguinis, 2009; Shore \& Strauss, 2008).

The findings furthermore show that a manager's previous experience, in both the capacity of ratee and rater, influences his or her attitude towards future performance appraisals. As ratees, managers' attitudes towards performance appraisal are influenced by their past experiences. These past experiences make them more familiar with the organisational processes and procedure and remind them of how they experienced receiving feedback, both positive and negative (Aguinis, 2009; Greguras, 2005). Consequently, managers 
who had favourable performance appraisal experiences in the past hold favourable attitudes towards this process, and managers who had unpleasant previous performance appraisals dislike giving negative feedback to their employees (Aguinis, 2009).

From the findings it is evident that the role senior management plays in performance appraisal influences managers' attitudes towards performance appraisal. The participants expressed their view that senior managers should be the drivers of the performance appraisal system and that it should be executed from the top downwards, emphasising the importance and value of the process to the organisation as a whole (Kondrasuk, 2012).

The findings furthermore stressed the ability of the performance appraisal framework to pose an ethical dilemma to managers. In a study conducted by Tziner et al. (2002), it is proposed that managers who perceive it to be acceptable to distort performance ratings would shy away from making conscious decisions to misrepresent performance ratings either in order to reach their own personal goals or to achieve the goals of the organisation. Shore and Strauss (2008) agree proclaiming that such frameworks originate from the organisational context and can instigate unethical behaviour on the part of the manager.

Evidence suggests an uncertainty between some managers as to the purpose of performance appraisal. This assertion is warranted as managers are not always clear on whether the performance appraisal is being used for administrative purposes (such as reward-related) or for the development of employees. Not being clear on the purpose of performance appraisal seems to be a prevalent complication within the sphere of performance appraisal and most certainly impacts negatively on attitudes, employee development and both employee and organisational performance as not everyone is steering in the same direction (Curtis et al., 2005; Kondrasuk, 2012; Marmet, 2015).

Similar to the challenges experienced pertaining to the purpose of the performance appraisal are challenges around uncertainty as to what should be measured. Managers are often challenged with measuring employees' tasks that are not properly defined, and this state of affairs results in uncertainty (Kondrasuk, 2012). In some positions it is straightforward and trouble-free to determine whether the person is performing, but other positions might be complex and time and effort might be required to assess whether the person is delivering according to expectations (Lawler, Benson \& McDermott, 2012). Jawahar (2001) claims that managers with positive attitudes towards performance appraisal will ensure that employees receive accurate performance appraisal ratings.

The findings indicate that the frequency of performance appraisal will affect managers' attitudes towards performance appraisal. It is also confirmed that the frequency or timing of performance appraisal is a problematic area for managers and this is one of the reasons why performance appraisal is viewed negatively (Kondrasuk, 2012).

According to the findings, managers seem to agree on the impact the type of feedback they need to give - in conjunction with their personalities - has on their overall attitude to performance appraisal. According to Marmet (2015), the rater's personality interacts with the context in which the appraisal occurs. Therefore, the type of feedback that needs to be given affects the manager's attitude and emotions and subsequently influences the rating (Belschak \& Den Hartog, 2009). Furthermore, managers dislike giving negative feedback to employees as such negative feedback affects the employee's career, causes defensive reactions and even promotes employee hostility (Thomas \& Bretz, 1994).

\section{Practical implications}

Although this research was conducted at a medium-sized financial services organisation in the private sector, the factors identified as influencing managers' attitudes towards performance appraisal have practical implications for any organisation that implements performance appraisals as part of its human resource management practices. The insight gained from this research can assist organisations to better support and empower managers to be more effective in their approach when conducting performance appraisals.

Performance appraisal appears to be a process during which both the manager and the employee feel uncomfortable, defensive and sometimes even emotional. Managers therefore tend to avoid employees with defensive and hostile attitudes and behaviour. It is recommended that organisations make use of multi-source appraisals to minimise emotional behaviour during performance appraisal. Organisations should however ensure that all raters have been sufficiently trained and that just in case an employee wishes to appeal against a rating, which process the raters should now follow.

However, if attention is not given to this state of affairs, the situation is exacerbated when managers experience uncertainties regarding the technical aspects of performance appraisal, such as the purpose of performance appraisal, timing and frequency of performance appraisal and what should be measured. It is recommended that managers should receive training regarding the technical aspects of performance appraisal.

Because of a lack of training, managers do not always have the ability and readiness to conduct performance appraisals, specifically when such performance appraisals will contain negative performance feedback. Managers draw from their experiences with performance appraisal as both ratee and rater and they need to be facilitated and trained in conducting performance appraisals, specifically performance appraisals containing negative feedback.

Furthermore, the organisational context might place managers in an undesirable position that leads them to 
distort employee performance ratings - unintentionally or deliberately. Senior management needs to drive performance appraisal and ensure that employees and management understand the purpose of performance appraisal and that they all work with the same goals in mind. Senior management also needs to cultivate a culture of ethical performance appraisal in which managers are held accountable for the performance ratings they assign to employees.

\section{Limitations and recommendations}

Although this study was successful in identifying the factors that influence manager attitudes towards performance appraisal, it had some limitations. Firstly, the findings of this study are representative participants employed in a mediumsized financial services organisation in the private sector and thus not representative of organisational contexts within other sectors. Secondly, a deeper understanding of the participants' previous employers and the performance appraisal systems they had been subject to could have provided a more in-depth view of their attitudes towards performance appraisal as well as the factors that influence these attitudes.

The findings of this study revealed the opinions and views of this sample of managers only. Therefore, in future research, the sample could include participants from different organisations and business sectors to ensure better representation. It is furthermore recommended for future research to also include the views of employees and senior management as to the factors that influence managers' attitudes towards performance appraisal.

\section{Conclusion}

It is crucial for organisations to be aware of factors that influence managers' attitudes towards performance appraisal. By taking cognisance of this fact, organisations might be better positioned to change managers' attitudes towards performance appraisal positively. From the findings of this study as well as from the literature it seems that an interrelationship exists between the defensive and emotional nature of performance appraisal, the technical uncertainties among managers, the readiness of managers to conduct performance appraisals and the organisational context and framework in which performance appraisal is conducted.

\section{Acknowledgements}

The authors wish to acknowledge the support provided by the Ethics Committee of the Department of Industrial and Organisational Psychology at Unisa in obtaining ethical clearance to conduct this research.

\section{Competing interests}

The authors declare that they have no financial or personal relationships that may have inappropriately influenced them in writing this article.

\section{Authors' contributions}

T.d.P. was the project leader. T.d.P. and A.v.N. were coresponsible for the experimental and project design. T.d.P. collected and analysed the data. A.v.N. performed the quality assuring of the data collection and data analysis process. T.d.P. and A.v.N. co-wrote the manuscript.

\section{References}

Adler, S., Campion, M., Colquitt, A., Grubb, A., Murphy, K., Ollander-Krane, R., et al. (2016). Getting rid of performance ratings: Genius or folly? A debate. Industrial and Organizational Psychology, 9(2), 219-252. https://doi.org/10.1017/iop. and Organ

Aguinis, H. (2009). Performance management. (2nd edn.). Upper Saddle River, NJ: Pearson Prentice Hall.

Allport, G.W. (1935). Attitudes. In C.A. Murchison (Ed.), A handbook of socia psychology (pp. 798-884). Worcester, MA: Clark University Press.

Babbie, E.R. (2010). The practice of social research. Belmont, CA: Wadsworth.

Bayo-Moriones, A., Galdon-Sanchez, J.E., \& Martinez-de-Morentin, S. (2016). Competitive strategy, performance appraisal and firm results. Retrieved October 05, 2016, from http://papers.ssrn.com/sol3/papers.cfm?abstract_id $=2810452$

Belschak, F.D., \& Den Hartog, D.N. (2009). Consequences of positive and negative feedback: The impact on emotions and extra-role behaviors. Applied Psychology, 58(2), 274-303. Retrieved October 09, 2016, from https://doi.org/10.1111/j. 58(2), 274-303. Retrieved

Botha, J. \& Bussin, M. (2010). Performance evaluation. In M. Coetzee \& A.M.G. Schreuder (Eds.), Personnel psychology: An applied perspective (pp. 1-67). Cape Town, South Africa: Oxford University Press.

Cascio, W.F., \& Aguinis, H. (2011). Applied psychology in human resource management. (7th edn.). Upper Saddle River, NJ: Pearson Prentice Hall.

Creswell, J.W. (2014). Research design: Qualitative, quantitative and mixed methods approaches. (4th edn.). Thousand Oaks, CA: Sage.

Curtis, A.B., Harvey, R.D., \& Ravden, D. (2005). Sources of political distortions in performance appraisals. Group and Organisation Management, 30, 42-60. https://doi.org/10.1177/1059601104267666

De Vos, A.S., Strydom, H., Schulze, S., \& Patel, L. (2012). The sciences and the professions. In A. De Vos, H. Strydom, C.B Fouche, \& C.S.L Delport (Eds.), Research at grassroots for the social sciences and human services professions (4th edn., pp. 28-44). Pretoria, South Africa: JL Van Schaik.

Durrheim, K., \& Painter, D. (2006). Collecting quantitative data: Sampling and measuring. In M. Terre Blanche, K. Durrheim \& D. Painter (Eds), Research in practice: Applied methods for the social sciences (pp. 131-159). Cape Town, South Africa: UCT Press.

Dusterhoff, C., Cunningham, J.B., \& MacGregor, J.N. (2014). The effects of performance rating, leader-member exchange, perceived utility and organizational justice on performance appraisal satisfaction: Applying a moral judgment perspective. Journal of Business Ethics, 119, 265-273. https://doi.org/10.1007/s10551-013$1634-1$

Eagly, A.H., \& Chaiken, S. (1993). The psychology of attitudes. Fort Worth, TX: Harcourt Brace Jovanovich.

Fazio, R.H., \& Petty, R.E. (2008). Attitudes: Key readings. New York: Psychology Press.

Giorgi, A. (1985). Phenomenology and psychological research. Pittsburgh, PA: Duquesne University Press.

Gordon, M.E., \& Stewart, L.P. (2009). Conversing about performance: Discursive resources for the appraisal interview. Management Communication Quarterly, 22(3), 473-501. https://doi.org/10.1177/0893318908327159

Greef, M. (2012). Information collection: Interviewing. In A. De Vos, H. Strydom, C. Fouché, \& C. Delport (Eds.), Research at grassroots for the social sciences and human service professions (4th edn., pp. 341-374). Pretoria, South Africa: JL Van Schaik.

Greguras, G.J. (2005). Managerial experience and the measurement equivalence of performance ratings. Journal of Business and Psychology, 19(3), 383-397. https:// doi.org/10.1007/s10869-004-2234-y

Grote, R.C. (2011). How to be good at performance appraisals: Simple effective, done right. Boston, MA: Harvard Business Review Press.

Harris, M.M. (1994). Rater motivation in the performance appraisal context: A theoretical framework. Journal of Management, 20(4), 737-756.

Henning, E., Van Rensburg, W., \& Smit, B. (2012). Finding your way in qualitative research. Pretoria, South Africa: JL Van Schaik.

Hii, L., \& Ahmad, R. (2015). Rater competency in conducting performance appraisal in the Malaysian public sector. International Journal of Social Science and Humanity, 5(1), 69-74. https://doi.org/10.7763/IJSSH.2015.V5.424

Jacobs, G., Belschak, F.D., \& Den Hartog, D.N. (2014). Unethical behaviour and performance appraisal: The role of affect, support and organizational justice. Journal of Business Ethics, 121, 63-76. https://doi.org/10.1007/s10551-0131687-1

Jawahar, I.M. (2001). Attitudes, self-monitoring and appraisal behaviors. Journal of Applied Psychology, 86(5), 875-888. https://doi.org/10.1037//0021-9010.86.5.875 
Katz, D. (1960). The functional approach to the study of attitudes. Public Opinion Quarterly, 24, 163-204. https://doi.org/10.1086/266945

Kolb, B. (2008). Marketing research: A practical approach. London: Sage.

Kondrasuk, J.N. (2012). The ideal performance appraisal is a format, not a form. Academy of Strategic Management Journal, 11(1), 115-130. Retrieved October 09, 2016, from http://0-search.proquest.com.oasis.unisa.ac.za/docview/ 1037692128/fulltextPDF/BF5854FF81404669PQ/8?accountid=14648

Lawler, E.E., Benson G.S., \& McDermott, M. (2012). What makes performance appraisals effective. Compensation and Benefits Review, 44(4), 191-200. https:// doi.org/10.1177/0886368712462331

Longenecker, C.O., \& Gioia, D.A. (2003). Confronting the politics in performance appraisal. Business Forum, 24(3), 17-23. Retrieved October 05, 2016, from http:// search.proquest.com/openview/c8fa85b763efb9d60ac601881f679338/1?pqorigsite=gscholar

Longenecker, C.O., Sims, H.P., \& Gioia, D.A. (1987). Behind the mask: The politics of employee appraisal. The Academy of Management Executive, 1(3), 183-193. Retrieved October 05, 2016, from https://www.tamu.edu/faculty/payne/PA/ Longenecker\%20et\%20al.\%201987.pdf

Luthans, F. (2008). Organizational behaviour. Boston, MA: McGraw Hill.

MacDonald, H.A., \& Sulsky, L.M. (2009). Rating formats and rater training redux: A context-specific approach for enhancing the effectiveness of performance
management. Canadian Journal of Behavioural Science, 41(4), 227-240. https:// management. Canadian Journ
doi.org/10.1037/a0015165

Marmet, M.D. (2015). The impact of rater personality and purpose of appraisal on performance ratings Unpublished doctoral dissertation, University of Connecticut, Storrs, CT.

Marreli, A.F. (2011). Problems and remedies in performance management. Industria and Organisational Psychology, 4(2),169-172.https://doi.org/10.1111/j.1754-9434. 2011.01317x

Mason, J. (2012). Qualitative researching. London: Sage.

Miserandino, M. (2007). Attitude formation. In R. Baumeister \& K. Vohs (Eds.) Encyclopedia of social psychology (pp. 66-68). Thousand Oaks, CA: Sage.

Pichler, S. (2012). The social context of performance appraisal and appraisal reactions: A meta-analysis. Human Resources Management, 51(5), 709-732. https://doi. org $/ 10.1002 / \mathrm{hrm} .21499$

Pietkiewicz, I., \& Smith, J.A. (2014). A practical guide to using interpretative phenomenological analysis in qualitative research psychology. Czasopismo Psychologiczne Psychological Journal, 20(1), 7-14. https://doi.org/10.14691/CPPJ. 20.1.7

Pratkanis, A.R. (2014). The cognitive representation of attitude. In A.R. Pratkanis, S.J. Breckler, \& A.G. Greenwald (Eds.), Attitude, structure and function (pp. 71-98) New York: Psychology Press.

Pulakos, E.D., \& O'Leary, R.S. (2011). Why is performance management broken? Industrial and Organisational Psychology, 4(2), 146-164. https://doi.org/10.1111/ Industrial and Organisation
j.1754-9434.2011.01315.x

Rossman, G.B., \& Rallis, F.S. (2011). Learning in the field: An introduction to qualitative research. (3rd edn.). London: Sage.

Schurink, W., Fouche, C.B., \& De Vos, A.S. (2012). Qualitative data analysis and interpretation. In A. De Vos, H. Strydom, C. Fouché, \& C. Delport (Eds.), Research at grassroots for the social sciences and human service professions (4th edn., pp. 397-423). Pretoria, South Africa: Van Schaik.
Shah, S., \& Corley, K. (2006). Building better theory by bridging the quantitativequalitative divide Journal of Management Studies, 43(8) 1823-1836. Retrieved October 09, 2016, from https://doi.org/10.1111/j.1467-6486.2006. 00662.x

Shore, T., \& Strauss, J. (2008). The political context of employee appraisal: Effects of organisational goals on performance ratings. International Journal of Management, 25(4), 599-612. Retrieved n.d., from http://search.proquest.com/ Management, 25(4), 599-612. Retrieved n.d., from http://search.proquest.cc
openview/b6b051105f7c4837e5703997e9845dcc/1?pq-origsite=gscholar

Swanepoel, S., Botha, P.A., \& Mangonyane, N.B. (2014). Politicisation of performance appraisals. SA Journal of Human Resource Management, 12(1), 1-9. https://doi. org/10.4102/sajhrm.v12i1.525

Thomas, S.L., \& Bretz, R.D. (1994). Research and practice in performance appraisal: Evaluating employee performance in America's largest companies. SAM Advanced Management Journal, 59(2), 28-34. Retrieved October 05, 2016, from http:// search.proquest.com/openview/6dcd301d72eac422a7bdba56bafa94a5/1?pqorigsite $=$ gscholar

Thurstone, L.L. (1931). The measurement of change in social attitude. Journal of Socia Psychology, 2(2), 230-235. https://doi.org/10.1080/00224545.1931.9918969

Torrington, D., Hall, L., Taylor, S., \& Atkinson, C. (2009). Fundamentals of human resource management. London: Pearson.

Tziner, A., Lathan, G.P., Price, B.S., \& Haccoun, R. (1996). Development and validation of a questionnaire for measuring perceived political considerations in performance appraisal. Journal of Organizational Behavior, 17, 179-190. Retrieved October 05, 2016, from http://www.jstor.org/stable/2488590?seq=1\#page_scan_tab_ contents

Tziner, A., \& Murphy, K.R. (1999). Additional evidence of attitudinal influences in performance appraisal. Journal of Business and Psychology, 13(3), 407-419. https://doi.org/10.1023/A:1022982501606

Tziner, A., Murphy, K.R., \& Cleveland, J.N. (2002). Does conscientiousness moderate the relationship between attitudes and beliefs regarding performance appraisal and rating behaviour. International Journal of Selection and Assessment, 10(3), 218-224. https://doi.org/10.1111/1468-2389.00211

Van De Mieroop, D., \& Vrolix, E. (2014). A discourse analytical perspective on the professionalization of the performance appraisal interview. International Journal of Business Communication, 51(2), 159-182. https://doi.org/10.1177/ 2329488414525197

Visagie, R.G., \& Maritz, J. (2009). Diversifying business coaching in a South African higher education context to facilitate research output. The International Journal of Diversity in Organisations, 9(3), 1-13. https://doi.org/10.18848/1447-9532/ CGP/v09i03/39737

Vogel, T., \& Wänke, M. (2016). Attitudes and attitude change. (2nd edn.). London: Routledge.

Yun, G.J., Donahue, L.M., Dudley, N.M., \& McFarland, L.A. (2005). Rater personality, rating format, and social context: Implications for performance appraisal ratings. International Journal of Selection and Assessment, 13(2), 97-107. https://doi org/10.1111/j.0965-075X.2005.00304.X

Zhang, X., Xie, F., Wee, H.L., Thumboo, J., \& Li, S.C. (2008). Applying the expectancyvalue model to understand health values. International Society for Pharmacoeconomics and Outcomes Research, 10(1), 61-68. https://doi.org/10. $1111 / \mathrm{j} .1524-4733.2008 .00368 . x$ 